\title{
STRATEGI PEMBIAYAAN TERHADAP PENGEMBANGAN PARIWISATA BERBASIS MASYARAKAT DI KOTA AMBON
}

\section{Financing Strategies for Community-Based Tourism Development in Ambon City}

\section{Olivia CH Latuconsina ${ }^{1}$, Yusman Syaukat ${ }^{2}$, dan Hermanto Siregar ${ }^{3}$}

\author{
1 Wakil Walikota Ambon periode 2006-2011. E-mail: mdpipb@hotmail.com \\ 2 Staff Pengajar Departemen Ekonomi Sumberdaya dan Lingkungan. Fakultas Ekonomi dan Manajemen IPB \\ E-mail: ysyaukat@gmail.com
}

${ }^{3}$ Staff Pengajar Departemen Ilmu Ekonomi. Fakultas Ekonomi dan Manajemen - Institut Pertanian Bogor.

E-mail: hermansiregar@yahoo.com

\begin{abstract}
Community-based tourism could increase local income and at the same time maintain the culture, arts and way of life of surrounding communities. The purpose of this research is to study the financing of community based tourism development in Ambon City. Methods used in this reseach are descriptive quantitative analysis, SWOT analysis, and QSPM analysis. Findings of the analysis are: 1) The role of government shoud be increased through friendly investment policy and sufficient government budget; 2) Increase in private financing done through the public private partnerships; 3) Communication, coordination and cooperation among local government and tourism entepreneurs are need to be improved; 4) Communities around the tourist objects can not yet utilize the potential of tourism as a source of their income so capacity building for them is a must; 5) Community can take advantage of the national program of tourism self empowerment (PNPM Mandiri Pariwisata) and "Kredit Usaha Rakyat" program to increase their welfare, and 6) There are six financing strategies for community-based tourism development in Ambon City that can be implemented in 2011-2016.
\end{abstract}

Keywords: Ambon, Community-based tourism, Financing, Policy, Public Private Partnerships

\begin{abstract}
ABSTRAK
Pariwisata berbasis kominitas dapat meningkatkan pendapatan masyarakat setempat dan sekitarnya sekaligus memelihara budaya, kesenian dan cara hidup masyarakat di sekitarnya. Tujuan penelitian adalah untuk mengkaji pembiayaan pengembangan pariwisata berbasis masyarakat di Kota Ambon. Metode yang digunakan yaitu analisis deskriptif kuantitatif, analisis SWOT, dan analisis QSPM. Hasil analisis yang ditemukan antara lain: 1) Perlu peningkatan peran pemerintah melalui kebijakan investasi dan anggaran yang cukup; 2) Peningkatan pembiayaan swasta melalui kemitraan sektor publik-swasta perlu dilakukan; 3) Komunikasi, koordinasi serta kerjasama antara pemerintah dan wirausaha pariwisata perlu ditingkatkan; 4) Komunitas di sekitar obyek wisata belum bisa memanfaatkan potensi pariwisata sebagai sumber pendapatan sehingga kapasitas pembangunan bagi komunitas perlu dilakukan; 5) Komunitas dapat mengambil keuntungan dari program nasional pemberdayaan masyarakat pariwisata (PNPM Mandiri Pariwisata) dan program "Kredit Usaha Rakyat" untuk meningkatkan kesejahteraan masyarakat; dan 6) Terdapat 6 strategi pembiayaan terkait pengembangan pariwisata berbasis komunitas di Kota Ambon yang dapat diterapkan pada 2011-2016.
\end{abstract}

Kata kunci: Ambon, Pariwisata Berbasis Komunitas, Pembiayaan, Kebijakan, Kemitraan Sektor Publik-Swasta

\section{PENDAHULUAN}

\section{Latar Belakang}

Pariwisata merupakan suatu kegiatan yang secara langsung menyentuh dan melibatkan masyarakat, sehingga membawa berbagai dampak terhadap masyarakat setempat. Pembangunan sektor pariwisata dapat memberikan berbagai manfaat, baik bagi masyarakat maupun terhadap pemerintah dan daerah tersebut. Sektor ini memberikan manfaat bagi masyarakat sekaligus bagi daerah dimana 
sektor ini dikembangkan karena dapat mendorong pengembangan ekonomi lokal seperti adanya peningkatan pendapatan masyarakat, peningkatan kesempatan kerja, serta adanya peluang berusaha.

Pengembangan ekonomi lokal di suatu daerah mendorong tercapainya peningkatan kesejahteraan bagi masyarakat yang dapat diukur dengan pengurangan kemiskinan di daerah tersebut. Sektor pariwisata berbasis masyarakat dapat menjadi salah satu alternatif pengentasan kemiskinan karena sektor tersebut memberikan kontribusi besar dalam meningkatkan kesejahteraan rakyat kecil sampai di perdesaan. Pariwisata diyakini dapat berfungsi sebagai katalisator dalam pembangunan atau sebagai agent of development sekaligus menjadi penggerak dalam mempercepat pembangunan itu sendiri (Yoeti, 2008).

Dengan julukan Ambon Manise, potensi pariwisata di Kota Ambon telah dikenal karena memiliki karakteristik khas dimana sebagian besar wilayahnya bukan saja terdiri dari pegunungan, perbukitan, pesisir pantai dan lautan namun juga memiliki nilai sejarah dan budaya yang cukup tinggi. Menurut Dinas Pariwisata Kota Ambon (2008), terdapat 45 lokasi wisata alam dan 24 lokasi wisata sejarah dan budaya, serta 378 industri pariwisata yang terdiri dari usaha perhotelan, restoran, biro perjalanan dan industri hiburan lainnya.

Namun demikian, sejak tahun 1999, pasca konflik sosial di Kota Ambon, pariwisata mengalami penurunan drastis dan memberikan pencitraan negatif Kota Ambon sebagai daerah konflik. Berbagai upaya dilakukan pemerintah Kota Ambon untuk memperbaiki (recovery) citra Kota Ambon, antara lain dilakukan dengan memperkenalkan lebih jauh berbagai daya tarik obyek wisata di Kota Ambon. Masyarakat Kota Ambon di sekitar obyek wisata belum secara optimal memanfaatkan potensi wisata yang dimiliki untuk peningkatan kesejahteraan mereka. Pariwisata berbasis masyarakat merupakan alat pengembangan masyarakat untuk memperkuat kemampuan masyarakat dalam mengelola sumbersumber pariwisata maupun meningkatkan partisipasi mereka.

Pengembangan sektor pariwisata berbasis masyarakat juga memberikan dampak positif bagi daerah berupa peningkatan pendapatan pemerintah melalui pajak dan retribusi, peningkatan penerimaan devisa serta dapat mendorong peningkatan investasi dari sektor industri pariwisata dan sektor ekonomi lainnya. Dengan diberlakukanya UU No. 32 tahun 2004 sebagai pengganti UU No. 22 Tahun1999 dan UU N0. 33 Tahun 2004 sebagai pengganti UU N0. 25 Tahun 1999 tentang pemerintah daerah dan perimbangan keuangan antara pusat dan daerah, maka daerah dituntut untuk selalu berupaya semaksimal mungkin dalam meningkatkan pendapatan asli daerah.

Alokasi dana di Anggaran Pendapatan dan Belanja Daerah (APBD) terhadap sektor ini tidak signifikan dibandingkan dengan potensi wisata yang dimiliki Kota Ambon. Di lain pihak, swasta pun kurang terlihat dalam berinvestasi di sektor ini. Keterbatasan pemerintah daerah dan swasta dalam membiayai pembangunan sektor pariwisata turut mempengaruhi perkembangan pariwisata di Kota Ambon, untuk itu perlu dilakukan kajian mengenai strategi dan program pembiayaan terhadap pengembangan pariwisata yang berbasis masyarakat serta mampu meningkatkan kesejahteraan masyarakat di Kota Ambon.

\section{Perumusan Masalah}

Kebijakan desentralisasi fiskal yang dilaksanakan di Indonesia memberikan kebebasan kepada pemerintah daerah untuk menyusun program kerja dan anggaran sesuai dengan kebutuhan dan kapasitas yang dimiliki daerah tersebut. Dengan kebijakan tersebut nantinya diharapkan pemerintah daerah akan lebih efektif memenuhi pelayanan publik dan membangun sarana perekonomian yang sesuai dengan kebutuhan masyarakat 
setempat. Dengan demikian akan tercipta lapangan pekerjaan yang pada akhirnya dapat meningkatkan pendapatan, kesejahteraan dan kemandirian masyarakat serta berpotensi menanggulangi masalah kemiskinan.

Mengacu pada hal tersebut, pemerintah Kota Ambon telah melakukan berbagai program pembangunan sesuai visi dan misi yang tertuang dalam Rencana Pembangunan Jangka Menengah (RPJM) Kota Ambon 2006-2011. Di dalam RPJM tersebut, tertuang Arah Kebijakan Umum Pembangunan Pariwisata Kota Ambon yang kemudian dijabarkan dalam bentuk program dan kegiatan RKPD Kota Ambon. Namun kebijakan pemerintah ini belum optimal dalam mendukung sektor pariwisata.

Dilihat dari Anggaran Pendapatan dan Belanja Daerah (APBD) Kota Ambon, belanja pemerintah untuk sektor pariwisata sangat tidak signifikan dibandingkan dengan potensi pariwisata yang ada di Kota Ambon. Pada tahun 2008, belanja pemerintah untuk sektor ini mencapai $\mathrm{Rp}$ 1,869 milyar dengan peneriman hanya sebesar Rp 120,34 juta dari total APBD sebesar Rp 479,93 milyar (Dinas Pariwisata Kebudayaan Pemuda \& Olahraga Kota Ambon, 2009).

Rendahnya alokasi belanja untuk subsektor pariwisata ini telah membatasi aktivitas kepariwisataan di Kota Ambon termasuk parwisata berbasis masyarakat. Keterbatasan alokasi dan pemanfaatan anggaran pemerintah juga berimplikasi terhadap kurang memadainya sarana dan prasarana pariwisata serta infrastruktur penunjang kegiatan kepariwisataan lainnya. Dari uraian dan permasalahan tersebut maka perlu dikaji sejauhmana kebijakan pemerintah daerah dalam mengembangkan sektor pariwisata yang berbasis masyarakat di Kota Ambon.

Berkembangnya kegiatan pariwisata berbasis masyarakat akan menggerakkan banyak mata rantai usaha yang terkait di dalamnya sehingga akan menciptakan multiplier effect yang akan memberikan nilai manfaat ekonomi yang sangat berarti bagi semua pihak yang terkait dalam mata rantai usaha kepariwisataan tersebut. Kegiatan pariwisata berbasis masyarakat juga dapat menjaga keberlangsungan eksoistem. Partisipasi masyarakat dalam melakukan kegiatan usaha kepariwisataan masih belum maksimal karena kegiatan usaha yang dilakukan sangat tergantung dari kunjungan wisatawan ke daerah tersebut. Di sisi lain, Pemerintah Kota Ambon masih terbatas dalam mengimplementasikan pendanaan secara fisik bagi pembangunan sarana dan prasarana serta fasilitas pendukung kepariwisataan lainnya. Untuk itu dibutuhkan keterlibatan pihak lain dalam hal ini swasta maupun masyarakat untuk mengembangkan pariwisata berbasis masyarkat di Kota Ambon.

Usaha pariwisata yang dikelola masyarakat kota Ambon masih berskala mikro dan kecil yang terbatas dalam permodalan dan sumberdaya keahlian. Mobilisasi dana berupa investasi dari pihak swasta baik yang berskala menengah maupun besar ke Kota Ambon diharapkan dapat memacu pengembangan sektor ini. Dari uraian dan permasalahan tersebut, maka perlu diketahui informasi mengenai sejauhmana pembiayaan yang dilakukan masyarakat, pemerintah, dan swasta dalam mengembangkan pariwisata yang berbasis masyarakat di Kota Ambon serta bagaimana pola kerjasama pembiayaan antara pemerintah, swasta dan masyarakat dalam pengembangan sektor pariwisata yang saling menguntungkan.

\section{Tujuan Penelitian}

Berdasarkan latar belakang dan perumusan masalah, maka tujuan utama dari kajian ini adalah merumuskan strategi dan program pembiayaan terhadap pengembangan pariwisata yang berbasis masyarakat di Kota Ambon dari tahun 2011-2016 untuk:

1. Mengevaluasi kebijakan pemerintah daerah terhadap pengembangan 
pariwisata berbasis masyarakat di Kota Ambon.

2. Mengevaluasi pembiayaan yang dilakukan masyarakat, pemerintah, dan swasta dalam pengembangan pariwisata berbasis masyarakat di Kota Ambon.

3. Merumuskan strategi, program dan pola-pola kerjasama pembiayaan antara pemerintah, swasta dan masyarakat dalam pengembangan kegiatan pariwisata yang saling menguntungkan.

\section{TINJAUAN PUSTAKA}

\section{Konsep Pariwisata Berbasis Masyarakat dan Ekonomi Pariwisata}

Menurut Cooper (1993), pariwisata adalah serangkaian kegiatan perjalanan yang dilakukan oleh perorangan atau keluarga atau kelompok dari tempat tinggal asalnya ke berbagai tempat lain dengantujuan melakukan kunjungan wisata dan bukan untuk bekerja atau mencari penghasilan di tempat tujuan.

Di dalam pasal 1 ayat 1 UndangUndang RI nomor 10 tahun 2009 , wisata adalah kegiatan perjalanan yang dilakukan oleh seseorang atau sekelompok orang dengan mengunjungi tempat tertentu untuk tujuan rekreasi, pengembangan pribadi, atau mempelajari keunikan daya tarik wisata yang dikunjungi dalam jangka waktu sementara, sedangkan pariwisataan sebagaimana pada pasal 1 ayat 3 UndangUndang RI No. 10 tahun 2009 adalah berbagai macam kegiatan wisata dan didukung berbagai fasilitas serta layanan yang disediakan oleh masyarakat, pengusaha, Pemerintah, dan Pemerintah Daerah. Kepariwisataan dijelaskan dalam pasal 1 ayat 4 Undang-Undang RI No. 10 tahun 2009 sebagai keseluruhan kegiatan yang terkait dengan pariwisata dan bersifat multidimensi serta multidisiplin yang muncul sebagai wujud kebutuhan setiap orang dan negara serta interaksi antara wisatawan dan masyarakat setempat, sesama wisatawan, Pemerintah,
Pemerintah Daerah, dan pengusaha. Ini menunjukkan pariwisata merupakan suatu aktivitas yang kompleks dengan suatu sistem yang besar yang terkait dengan berbagai komponen seperti ekonomi, ekologi, politik, sosial, budaya, dan lainlain.

Leiper (1979) menyebutkan bahwa sistem pariwisata terdiri atas tiga komponen utama yaitu, daerah asal (origin), daerah tujuan (destination) dan daerah antara (routes). Dalam sistem pariwisata, ada tiga pilar utama yang berperan dalam menggerakkan sistem tersebut, yaitu masyarakat, swasta dan pemerintah. Yang termasuk masyarakat adalah masyarakat umum yang ada pada destinasi termasuk juga tokoh-tokoh masyarakat, intelektual, LSM, dan media masa. Kelompok swasta adalah asosiasi usaha pariwisata dan para pengusaha, sedangkan pemerintah adalah berbagai wilayah administrasi mulai dari pemerintah pusat, provinsi, kabupaten dan kecamatan (Pitana dan Gayatri, 2005).

Pada bulan Juli 2000, Bank Dunia mulai memikirkan bagaimana caranya menanggulangi masalah kemiskinan melalui sektor pariwisata yang kemudian dikenal dengan community-based tourism (CBT). Selanjutnya diidentifikasi adanya tiga kegiatan pariwisata yang dapat mendukung konsep CBT yakni adventure travel, cultural travel, dan ecotourism. Bank Dunia yakin bahwa peningkatan wisata adventure, ecology dan budaya akan mampu meningkatkan pendapatan masyarakat setempat dan sekitarnya sekaligus memelihara budaya, kesenian dan cara hidup masyarakat disekitarnya. Selain itu, CBT akan melibatkan pula masyarakat dalam proses pembuatan keputusan, dan dalam perolehan bagian pendapatan terbesar secara langsung dari kehadiran para wisatawan. Sehingga dengan demikian CBT akan dapat menciptakan kesempatan kerja, mengurangi kemiskinan dan membawa dampak positif terhadap pelestarian lingkungan dan budaya asli setempat yang pada akhirnya diharapkan akan mampu 
menumbuhkan jati diri dan rasa bangga dari penduduk setempat yang tumbuh akibat peningkatan kegiatan pariwisata (Santosa, 2002).

Community Based Tourism ini merupakan ekonomi kerakyatan di sektor riil, yang langsung dilaksanakan oleh masyarakat dan hasilnyapun langsung dinikmati oleh mereka, dengan fokus pada wisatawan nusantara (wisnus) yang perannya sangat besar dalam menumbuhkan dan mengembangkan obyek-obyek wisata yang nantinya diharapkan akan dikunjungi oleh wisatawan mancanegara (wisman). Obyekobyek wisata yang sering dan padat dikunjungi oleh wisnus akan memperoleh manfaat lebih besar dibandingkan dengan yang jarang dikunjungi.

Menurut Goodwin (2004), pariwisata dapat berkontribusi dalam mengurangi kemiskinan dan pada beberapa daerah pariwisata merupakan salah satu variabel strategis dalam pembangunan ekonomi. Pro-poor tourism bukanlah salah satu produk khas dari pariwisata, melainkan merupakan suatu pendekatan pembangunan dan manajemen pariwisata, dimana masyarakat miskin mendapatkan keuntungan ekonomi secara aman dari pariwisata secara berkelanjutan. Pariwisata berbasis masyarakat dapat meningkatkan kehidupan masyarakat miskin dalam tiga cara, yaitu: (1) Tenaga kerja dan pengembangan usaha mikro, (2) Infrastruktur jalan, air bersih, listrik, telekomunikasi dan pengolahan sampah dan (3) Pemberdayaan dalam pengambilan keputusan.

Dalam mengimplementasikan pembangunan berbasis masyarakat atau community based development pada sektor pariwisata harus melibatkan pemerintah daearah dalam bentuk kebijakan-kebijakan untuk memberikan kemudahan dalam mendapatkan akses terhadap berbagai sumberdaya yang dimiliki, serta partisipasi pihak swasta dalam bentuk pendanaan. 66 Pembanguan sector pariwisata yang berbasis komunitas atau masyarakat memberikan kontribusi dalam upaya pengurangan kemiskinan di wilayah tersebut. Masyarakat setempat dapat diberdayakan dengan keterlibatan atau partisipasi mereka dalam turut meningkatkan potensi pariwisata di daerah mereka seperti melalui industri rumahan (home industry) pembuatan cinderamata berupa kerajinan tangan maupun produk seni dan budaya tradisional yang dapat memberikan pendapatan untuk kesejahteraan mereka.

Sebele (2009) menyatakan bahwa masyarakat hanya dapat menjadi peserta aktif jika mereka memiliki dukungan dari pemerintah, sektor swasta dan LSM untuk mentransfer pengetahuan dan keahlian. Hal ini hanya dapat dicapai melalui kebijakan dan kerangka kerja yang memaksimalkan potensi penuh dari masyarakat lokal. Sementara pada saat yang sama memastikan bahwa keuntungan dari pariwisata lebih besar daripada biayanya. Berbagai pemangku kepentingan di masyarkat termasuk pemerintah, wisatawan, masyarakat di sekitar obyek wisata, tur operator dan pelaku usaha kepariwisataan lainnya harus mengambil tanggung jawab secara etis dan sesuai kode etik (Fennell, 1999; Herremans \& Welsh, 1999). Pengambilan keputusan dan proses pembangunan memerlukan keterlibatan berbagai pemangku kepentingan pada semua tingkatan perencanaan dan pembuatan kebijakan, membawa bersamasama pemerintah, LSM, penduduk, industri dan para profesional dalam kemitraan yang menentukan jumlah dan jenis pariwisata yang diinginkan masyarakat (Choi dan Sirakaya, 2005).

Ekonomi pariwisata adalah suatu besaran ekonomi yang diciptakan oleh transaksi yang dilakukan antara para wisatawan (terkait dengan pengeluaran belanja wisata) dengan sektor-sektor ekonomi penyedia barang dan jasa (Heriawan, 2004). Australian Bureau of Statistic, ABS (1994) membagi ekonomi pariwisata dalam tiga elemen, yaitu wisatawan, transaksi, dan sektor/unit.

Wisatawan merupakan komponen terpenting dalam ekonomi pariwisata. 
Sebagai sesuatu kekuatan permintaan, jumlah wisatawan dan kemampuan belanjanya akan banyak menentukan besarnya penyediaan (supply-induced tourism), sementara itu keinginan untuk berwisata serta keinginan mengeluarkan belanja (willing to pay) akan dipengaruhi oleh harga yang harus dibayar serta lingkungan strategis yang ada di sekitar wisatawan, baik yang bersifat internal dan eksternal maupun langsung dan tidak langsung (Heriawan, 2004).

Cooper (1993), memperkenalkan model Schmoll yang menjelaskan bahwa keputusan mengenai tujuan wisata, lama tinggal, dan dana yang akan dikeluarkan akan tergantung oleh empat komponen utama yaitu, (1) Faktor pendorong, yaitu kekuatan yang mendorong seseorang untuk bepergian (willing to travel); advertensi dan promosi, buku/booklet wisata, saran dan cerita dari wisatawan terdahulu dan rekomendasi agen perjalanan. (2) Faktor individu dan sosial yaitu, kondisi dan sifatsifat yang melekat pada wisatawan itu sendiri; status sosial dan ekonomi, pertilaku personal, pengaruh sosial, sikap dan nilai lingkungan. (3) Variabel eksternal, yaitu gambaran tentang kondisi dan situasi perjalanan dan tempat tujuan wisata; keyakinan tentang keselamatan dan kemampuan operator wisata, citra mengenai daerah tujuan wisata dan pelayanannya, pengalaman perjalanan sebelumnya, keterjangkauan pada objek wisata, serta keterbatasan biaya dan waktu yang dimiliki. (4) Karakteristik pelayanan di tempat tujuan, yaitu kondisi, situasi, dan citra dari negara/daerah tujuan dan objek wisata; hubungan biaya dan manfaat yang diperoleh, atraksi dan objek yang ditawarkan, jangkauan perjalanan, kualitas dan kuantitas informasi perjalanan, dan paket-paket perjalanan yang ditawarkan (Heriawan, 2004)

Wagner (1996) melakukan studi dengan menggunakan model Input-Output (I-O) dan Social Accounting Matrix (SAM) untuk melihat dampak ekonomi dari ecoturism di daerah Protecao, Brasil. Hasil studi menunjukkan bahwa dampak ecoturism di daerah tersebut sangat kecil, karena sebagian besar kegiatan ekonomi menggunakan bahan impor. Hanya kegiatan peternakan dan pertanian di perdesaan yang sedikit menonjol karena mengekspor outputnya, namun kegiatan ini hanya memiliki sedikit interaksi dengan kegiatan bisnis lokal. Jika kegiatan ecoturism dapat dikembangkan dengan membeli output dari hasil pertanian lokal (seperti restoran membeli sayur-sayuran dari hasil pertanian setempat) dan membeli souvenir dari pengrajin setempat, maka konsumsi turis akan menciptakan keuntungan ekonomi yang lebih baik bagi daerah tersebut. Apalagi jika modal untuk membangun bisnis pariwisata ini juga berasal dari dana setempat (koperasi), maka keuntungan bisnis akan tetap berada di daerah tersebut dan terdistribusi bagi anggota-anggotanya.

\section{Pembiayaan Pembangunan}

Pembiayaan atau pendanaan merupakan kunci utama keberhasilan pembangunan. Adapun sumber penerimaan daerah dalam melaksanakan desentralisasi terdiri dari pendapatan daerah dan pembiayaan yang terdiri dari Pendapatan Asli Daerah (PAD), Dana Perimbangan, dan Lain-lain PAD yang sah. Heriawan (2004) melakukan penelitian tentang peranan dan dampak pariwisata pada perekonomiaan Indonesia dengan menggunakan model Input-Output (I-O) dan Sistem Neraca Sosial Ekonomi (SNSE). Dari hasil penelitian tersebut terlihat bahwa peningkatan APBN dan APBD sektor pariwisata merupakan pilihan utama dalam upaya memberi porsi pendapatan pada pekerja dan rumahtangga secara umum dengan lebih baik, namun kurang memberi peluang pada porsi pendapatan pekerja pertanian yang lebih baik.

Menurut Chib (1980), insentif utama untuk membuat proyek-proyek pariwisata yang layak akan disubsidi pinjaman jangka panjang, penyediaan lahan yang nilainya kurang dari nilai pasar, 
tax holiday untuk periode lima sampai sepuluh tahun, pengembangan investasi rabat atau pengembalian dana tunjangan secara penuh atau sebagian dari bea cukai maupun pembebasan pajak untuk pengeluaran promosi dan lain-lain. Ketersediaan keuangan dapat bersumber dari sumber-sumber asing, bank ataupun investasi swasta yang diatur dengan berbagai pertimbangan. Beberapa sumber tersebut dapat diterapkan bahkan untuk pinjaman antar lembaga keuangan pemerinmtah (Chib, 1980).

Hal ini menunjukkan bahwa pemerintah daerah semestinya dapat melakukan berbagai kebijakan dalam membiayaai sektor pariwisata khususnya pariwisata berbasis masyarakat, karena menurut Chib (1980), aspek penting dari kebijakan pariwisata akan menjadi kuantum insentif atau tindakan mempromosikan investasi dalam pembangunan pariwisata.

Pembiayaan pembangunan di Kota Ambon khususnya dalam sektor pariwisata tidak saja bersumber dari pemerintah melainkan dapat pula melalui kemitraan aktif swasta sehingga mampu melakukan kegiatan usaha yang memberikan nilai tambah dan menciptakan lapangan kerja. Untuk itu diperlukan rekayasa pembiayaan pembangunan yang tidak bersifat konvensional melainkan berdasarkan kemitraan dengan sektor publik dan swasta.

Menurut Saleh (2008), kemitraan dalam berinvestasi dapat berupa: (1) Pemberian kemudahan berinvestasi dan (2) Kemitraan Sektor Publik dan Swasta (public private partnerships). Model kemitraan sektor publik dan swasta tersebut antara lain dapat berupa partnership companies, private finance initiatives dan partnership investments. Partnership companies atau perusahaan berkemitraan adalah masuknya kepemilikan sektor swasta ke dalam BUMN/BUMD, dengan tetap menjamin atau mengedepankan kepentingan publik dan tujuan kebijakan publik melalui pengaturan, legislasi, perjanjian kemitraan, atau menahan saham khusus pemerintah (Saleh, 2008).

\section{Private Finance Initiative atau} prakarsa pendanaan swasta merupakan kontrak jangka panjang sektor swasta untuk membeli kualitas pelayanan sektor publik dengan tingkat kinerja tertentu, termasuk memelihara dan membanguan infrastruktur tertentu. Hal ini dapat dilakukan melalui pertama, pengkajian yang lebih mendalam dalam rangka pembangunan infrastruktur yang dibiayai melalui pembagian komposisi antara pemerintah dan swasta bagi pembangunan infrastruktur, kedua, penyiapan regulasi dan prosedur pembangunan infrastruktur, ketiga, penyiapan mekanisme dan pengawasan pembangunan infrastruktur, serta penyiapan informasi tentang jenis dan lokasi infrastruktur yang dibiayai melalui pembagian komposisi antara pemerintah dan swasta bagi pembangunan infrastruktur.

Kemitraan berinvestasi atau partnership investments adalah model dimana sektor publik memberikan kontribusi pendanaan pada investasi proyek sektor swasta, sehingga sektor publik akan memperoleh bagi hasil dari investasi tersebut. Model kemitraan di atas dapat diaplikasikan dalam bentuk kontrak pelayanan (service contract) atau outsourcing, kontrak manajemen (management contract), penyewaan (leases), konsesi (concessions), bangun operasi alih (build operate transfer-BOT), serta divestasi sebagian atau penuh (full or partial duivesture).

\section{Konsep Kerjasama Antar Daerah dalam Pengembangan Pariwisata}

Pengembangan

pariwisata merupakan salah satu bagian dari konsep pengembangan jaringan. Baiquni (2004), memberikan konsep tentang jaringan antar kota: Kota dengan segala fasilitas dan keunggulan teknologi serta aksesibilitas menjadi jaringan global, jaringan bisnis yang global yang memanfaatkan jaringan informasi untuk menentukan keputusan 
investasi, pilihan industri yang akan dibangun berdasarkan kecenderungan selera konsumen individual, maka untuk menangkap selera konsumen yang dimanifestasikan melalui selera pasar pariwisata akan memaksa pelaku bisnis pariwisata mengenbangkan suatu konsep jaringan serta kerjasama antar jaringan.

Pola pengembangan jaringan pariwisata memerlukan kerjasama antar jaringan baik di sektor publik yaitu pemerintah daerah maupun sektor swasta selaku pelaku bisnis pariwisata. Wahab (1992) mengemukakan bahwa pengembangan terhadap suatu kawasan pariwisata yang di dalamnya melibatkan berbagai pihak merupakan bentuk interaksi pemasaran pariwisata terhadap pasar wisata. Aplikasi yang dilakukan para pelaku pariwisata meliputi pasar wisata, pasar wisata budaya, pasar wisata konvensi, pasar wisata utama dan kondisi hari libur.

Kota Ambon sebagai ibukota Provinsi merupakan pintu masuk kepariwisataan di Provinsi Maluku. Jaringan kerjasama dengan kabupatenkabupaten lain di Provinsi Maluku merupakan salah satu upaya akselerasi pembangunan pariwisata di Kota Ambon.

Jay's (2008) melakukan penelitian tentang model kerjasama antar daerah dalam pengelolaan kawasann wisata antar daerah kabupaten Malang, Kota Malang dan Kota Batu dengan menggunakan metode kualitatif dan deskriptif analitis evaluatif dengan menggunakan pendekatan reprospektif dan prospektif. Pendekatan reprospektif untuk melakukan evaluasi kelebihan dan kelemahan pengembangan kawasan pariwisata antar daerah sedangkan pendekatan prospektif digunakan untuk pengembangan model kerjasama antar kelembagaan, antar daerah, maupun antar pelaku bisnis pariwisata. Hasil penelitian ini adalah Malang Raya yang merupakan ikon dalam pengembangan kawasan wisata antara Kabupaten Malang, Kota Malang dan Kota Batu yang pada kenyataannya kerjasama tersebut masih merupakan wacana dan belum terealisasi secara konkret dengan indikator belum adanya dokumen resmi tentang kebijakan kerjasama tersebut dan kebijakan pengembangan pariwisata masih bersifat parsial pada masing-masing daerah. Hal tersebut terkendala karena ego sektoral dan ego kepentingan dari masingmasing daerah dan ketiadaan dukungan politik baik dari eksekutif maupun legislatif.

\section{Kerangka Pemikiran}

Kota Ambon, sejak dahulu telah dikenal karena potensi sumberdaya alamnya, baik di darat maupun di laut, termasuk keanekaragaman budaya dan sejarah. Potensi ini sangat baik bila dikelola dalam sektor pariwisata karena dipercaya mampu memberikan kontribusi yang signifikan dalam upaya pengurangan kemiskinan serta peningkatan kualitas hidup masyarakat. UU No. 32 tahun 2004, telah memberikan kewenangan pengelolaan potensi pariwisata di daerah kepada pemerintah daerah, namun menjadi suatu hal yang dilematis. Di satu sisi pemerintah kota Ambon memiliki kewenangan luas dalam melaksanakan berbagai aspek pembangunan kepariwisataannya, namun di sisi lain pemerintah Kota Ambon mempunyai tanggung jawab yang semakin berat untuk membiayai pembangunan tersebut.

Namun pengalokasian dana dari pemerintah pusat untuk membiayai sektor ini belum terlihat. Pemerintah daerah pun belum mampu mengelola secara optimal sumber-sumber pendapatan daerahnya bagi pengembangan sektor pariwisata. Alokasi dana di Anggaran Pendapatan dan Belanja Daerah (APBD) terhadap sektor ini tidak signifikan. Di lain pihak, swasta juga kurang terlihat dalam berinvestasi di sektor ini. Dengan melakukan analisis deskriptif, dilakukan evaluasi terhadap kebijakan pemerintah Kota Ambon dalam mengembangkan pariwisata berbasis masyarakat maupun untuk mengevaluasi pembiayaan yang dilakukan baik oleh masyarakat, pemerintah maupun dan 
swasta dalam upaya pengembangan pariwisata berbasis masyarakat di Kota Ambon.

Untuk menjawab permasalahan strategi pembiayaan dapat dianalisis dengan mengacu pada skim-skim pembiayaan yang dapat dilakukan baik oleh pemerintah, swasta maupun masyarakat. Pola pembiayaan dapat melalui pola kemitraan atau Public Private Partnerships (PPP) antara pemerintah dengan swasta dengan aplikasi model
Kontrak Pelayanan, Kontrak Manajemen, Penyewaan, Konsesi, BOT dan Divestasi. Untuk mendapatkan strategi dan kebijakan terhadap akselerasi sektor pariwisata, digunakan analisis SWOT. Selanjutnya dilakukan perumusan dan perancangan program dengan analisis Quantitative Strategic Planning Matrix (QSPM). Perancangan program dilakukan untuk tahun 2011-2016. Selengkapnya kerangka pemikiran kajian ini disajikan pada Gambar 1.

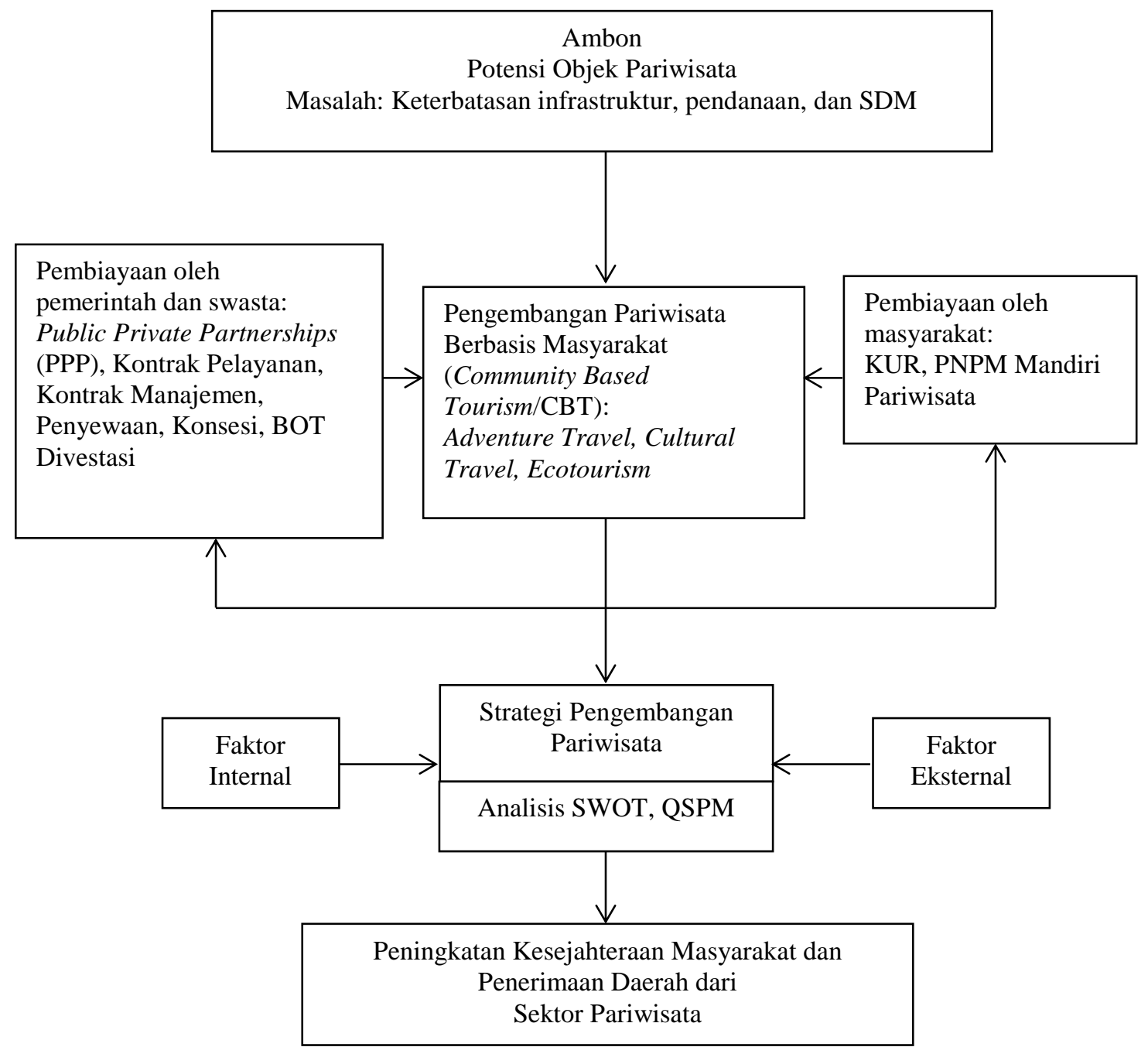

Gambar 1. Kerangka Pemikiran

\section{METODE PENELITIAN}

\section{Lokasi dan Waktu Penelitian}

Kajian dilaksanakan di Kota Ambon, ibukota Provinsi Maluku dengan pertimbangan bahwa selain karena daerah ini memiliki keunggulan pariwisata namun belum dapat dikembangkan secara optimal, juga karena merupakan pintu masuk dan tempat persinggahan (transit) dari para wisatawan yang akan mengunjungi tempattempat lain di wilayah Provinsi Maluku yang merupakan wilayah kepulauan. Kajian ini dilakukan selama satu bulan dari bulan November sampai Desember 2009. 


\section{Jenis dan Sumber Data}

Sumber data yang digunakan dalam penelitian ini berupa data sekunder dan data primer. Lebih lengkapnya bisa dilihat pada Tabel 1.

Tabel 1. Data dan Metode Analisis

\begin{tabular}{|c|c|c|c|c|}
\hline \multirow{2}{*}{\multicolumn{2}{|c|}{ Tujuan Kajian }} & \multicolumn{2}{|c|}{ Data } & \multirow{2}{*}{$\begin{array}{l}\text { Metode } \\
\text { Analisis }\end{array}$} \\
\hline & & Jenis & Sumber & \\
\hline 1 & $\begin{array}{l}\text { Mengevaluasi kebijakan pemerintah } \\
\text { daerah dalam pengembangan } \\
\text { pariwisata berbasis masyarakat di } \\
\text { Kota Ambon }\end{array}$ & $\begin{array}{l}\text { RPJMD, APBD, } \\
\text { RIPPDA, Laporan } \\
\text { Dinas }\end{array}$ & $\begin{array}{l}\text { BPS, Bappeda, } \\
\text { Dinas Pariwisata }\end{array}$ & $\begin{array}{l}\text { Deskriptif } \\
\text { Kuantitatif }\end{array}$ \\
\hline 2 & $\begin{array}{l}\text { Mengevaluasi pembiayaan yang } \\
\text { dilakukan masyarakat, pemerintah, } \\
\text { dan swasta dalam pengembangan } \\
\text { sektor pariwisata yang berbasis } \\
\text { masyarakat di Kota Ambon }\end{array}$ & $\begin{array}{l}\text { APBD, Kebijakan } \\
\text { Investasi }\end{array}$ & $\begin{array}{l}\text { Bappeda, Dinas } \\
\text { Pariwisata, } \\
\text { KADIN }\end{array}$ & $\begin{array}{l}\text { Deskriptif } \\
\text { Kuantitatif }\end{array}$ \\
\hline 3 & $\begin{array}{l}\text { Merumuskan strategi, program dan } \\
\text { pola-pola kerjasama pembiayaan } \\
\text { antara pemerintah, swasta dan } \\
\text { masyarakat dalam pengembangan } \\
\text { sektor pariwisata yang saling } \\
\text { menguntungkan }\end{array}$ & $\begin{array}{l}\text { RPJM, } \\
\text { RIPPDA, } \\
\text { Investasi } \\
\text { swasta dan } \\
\text { masyarakat }\end{array}$ & $\begin{array}{l}\text { Bappeda, } \\
\text { Dinas Pariwisata, } \\
\text { KADIN, } \\
\text { pengusaha industri } \\
\text { wisata, masyarakat } \\
\text { sekitar }\end{array}$ & $\begin{array}{l}\text { Analisis } \\
\text { SWOT } \\
\text { Analisis } \\
\text { QSPM }\end{array}$ \\
\hline
\end{tabular}

\section{Metode Analisis}

Metode pengolahan dan analisis yang digunakan pada penelitian yaitu:

1. Analisis deskripsi kuantitatif, digunakan untuk mengevaluasi kebijakan pemerintah daerah dalam pengembangan pariwisata berbasis masyarakat di Kota Ambon.

2. Analisis SWOT (Strength Weakness Opportunity Threat) untuk merumuskan strategi, program dan pola-pola kerjasama pembiayaan antara pemerintah, swasta dan masyarakat dalam pengembangan kegiatan pariwisata yang saling menguntungkan.

3. Quantitative Strategic Planning Matrix (QSPM) untuk perumusan strategi dan perancangan program.

\section{HASIL DAN PEMBAHASAN}

\section{Kebijakan Pemerintah Kota Ambon dalam Pengembangan Pariwisata Berbasis Masyarakat}

Di dalam Rencana Pembangunan Jangka Menengah (RPJM) Kota Ambon 2006-2011, tertuang Arah Kebijakan Umum pembangunan pariwisata Kota Ambon yang salah satunya diarahkan untuk meningkatkan, mengembangkan dan melestarikan obyek-obyek wisata serta daya tarik wisata melalui promosi dan pemasaran. Arah kebijakan umum tersebut kemudian diimplementasikan di dalam Rencana Kerja Pemerintah Daerah (RKPD). Dalam rangka menunjang pelaksanaan program kepariwisataan, pemerintah daerah juga telah menyusun Rencana Induk Pengembangan Pariwisata Daerah (RIPPDA) Kota Ambon yang ditujukan untuk perwujudan pembangunan dan pengembangan kepariwisataan sebagai penjabaran dari Rencana Induk Pengembangan Pariwisata Daerah (RIPPDA) Provinsi Maluku dan Rencana 
Induk Pengembangan Pariwisata Nasional (RIPPNAS).

Mengacu pada kegiatan-kegiatan kepariwisataan yang tertuang di dalam RKPD Kota Ambon, maka terlihat bahwa kegiatan-kegiatan tersebut belum sesuai dengan yang diamanatkan di dalam RPJM Kota Ambon 2006-2011. Kegiatankegiatan di dalam RKPD hanya mengimplementasikan dua kebijakan dalam RPJM Kota Ambon 2006-2011, yaitu: 1) Meningkatkan, mengembangkan dan melestarikan obyek-obyek wisata serta daya tarik wisata melalui promosi dan pemasaran dan 2) Meningkatkan kualitas aparatur dan peran serta masyarakat dalam menunjang pengembangan pariwisata. Namun progran-program dari kedua kebijakan tersebut belum secara fokus terimplementasi.

Program peningkatan kemitraan ternyata tidak diimplementasikan dengan baik karena hanya melakukan kegiatan studi banding serta menghadiri seminar dan diklat-diklat. Program ini seharusnya lebih diarahkan pada membentuk jaringan kerjasama kawasan pariwisata (networking) baik secara regional, maupun antar daerah di wilayah Provinsi Maluku. Pemerintah Kota Ambon telah melakukan berbagai program pembangunan tetapi belum optimal dalam mendukung sektor pariwisata yang juga merupakan sektor pembentuk Produk Domestik Regional Bruto (PDRB) yang dominan. Dalam upaya mendorong peningkatan investasi di daerah sepanjang tahun 2008 telah dialokasikan ke dalam satu program yaitu Program Promosi dan Kerjasama Investasi.

Menurut data BPS tahun 2009, realisasi pendapatan daerah Kota Ambon pada tahun 2007, sebesar Rp 436,135 milyar, atau 103,45 persen melampaui dari yang sudah dianggarkan, dan realisasi belanja daerah Kota Ambon adalah sebesar Rp 389,797 milyar atau hanya 83,52 persen dari yang sudah dianggarkan. Dari realisasi tersebut, sektor pariwisata pada tahun yang sama (2007) hanya mampu menerima Rp 115.73 juta dan melakukan belanja sebesar Rp 2,325 milyar.

\section{Evaluasi Pembiayaan oleh Masyarakat, Pemerintah dan Swasta dalam Pengembangan Pariwisata Berbasis Masyarakat}

Dari hasil wawancara dengan responden terkait peran masyarakat terhadap pengembangan pariwisata di Kota Ambon terungkap bahwa masyarakat bersedia memanfaatkan rumah mereka sebagai homestay (60\%) dan bersedia untuk mengelola makanan khas daerah untuk dijual kepada wisatawan (80\%). Meskipun 40 persen responden menyatakan akses dari dan ke obyek wisata sudah baik, namun responden juga menyatakan keberadaan obyek wisata masih kurang baik (80\%), sarana rekreasi masih kurang (80\%), promosi kepariwisataan yang dilakukan pemerintah masih kurang baik $(60 \%)$, dan responden menyatakan kurang mendapatakan informasi tentang pengembangan potensi pariwisata dari pemerintah bahkan belum mengetahui program kepariwisataan daerah (60\%). Dari segi pembiayaan, 80 persen responden menyatakan belum memiliki modal untuk mengembangkan usaha kepariwisataan di daerah mereka dan bersedia untuk dibantu permodalan baik oleh pemerintah maupun swasta.

Pengembangan pariwisata berbasis masyarakat di Kota Ambon dilakukan dengan memberikan perkuatan modal bagi mereka yang sudah memiliki usaha, contohnya melalui KUR dan PNPM Mandiri. Di Provinsi Maluku sampai dengan akhir Desember 2008, penyaluran KUR telah mencapai Rp 72,9 miliar untuk 6.304 nasabah. Selain itu, Kota Ambon, Buru dan Banda merupakan daerah yang menyerap dana KUR terbanyak sebesar Rp 36,7 miliar (50,3\%). Program KUR Biasa dan KUR Mikro diharapkan masyarakat di sekitar lokasi obyek wisata di Kota Ambon maupun bagi pengrajin yang tidak berada langsung dekat dengan obyek wisata tetapi sebagai produsen cinderamata khas daerah serta pelaku usaha pariwisata skala mikro dan kecil lainnya dapat memanfaatkan program tersebut untuk peningkatan 
produksi usaha mereka yang akan bermuara pada peningkatan pendapatan dan penciptaan lapangan kerja. Selain itu, dengan PNPM Mandiri Pariwisata, pemerintah dapat melakukan program pengembangan desa wisata dan masyarakat sadar wisata.

Hasil evaluasi pembiayaan oleh pemerintah menunjukkan bahwa walaupun sarana dan prasarana umum seperti jalan dan listrik telah dibangun pemerintah Kota Ambon, namun belum secara fokus dan optimal mengimplementasikan pendanaan secara fisik bagi pembangunan sarana dan prasarana serta fasilitas pendukung kepariwisataan lainnya. Hasil wawancara mengungkapkan bahwa obyek wisata kurang berkembang karena tidak dikelola oleh swasta $(80 \%)$ serta belum ada kerjasama antara Pemda dan swasta baik skala kecil, menengah maupun besar untuk mengembangkan pariwisata daerah $(80 \%)$,

\section{Perumusan Strategi dan Perancangan Program}

Analisis Perumusan alternatif strategi pembiayaan terhadap akselerasi pengembangan pariwisata berbasis masyarakat di Kota Ambon untuk tahun 2011-2016 dilakukan melalui tiga tahap, yaitu tahap masukan dengan melakukan identifikasi faktor internal dan eksternal, tahap penggabungan, dan tahap pengambilan keputusan. Analisis menghasilkan rumusan strategi pembiayaan terhadap pengembangan pariwisata di Ambon dalam bentuk matriks SWOT (Tabel 2).

Tabel 2. Matriks SWOT Perumusan Strategi Pembiaayan terhadap Pengembangan Pariwisata Berbasis Masyarakat di Kota Ambon

\begin{tabular}{|c|c|c|}
\hline Faktor Internal & $\begin{array}{l}\text { Kekuatan (Strengths) } \\
\text { S1. Potensi wisata alam dengan } \\
\text { karakteristik khas. } \\
\text { S2. Potensi wisata budaya dan } \\
\text { sejarah } \\
\text { S3. Kebijakan Pemerintah Daerah } \\
\text { S4. Keberadaan Maluku Tourism } \\
\text { Board } \\
\text { S5. Otonomi daerah }\end{array}$ & $\begin{array}{l}\text { Kelemahan (Weaknesses) } \\
\text { W1. Sumberdaya keuangan yang } \\
\text { terbatas baik dari pemda } \\
\text { maupun swasta } \\
\text { W2. Pola kerjasama pemda dan } \\
\text { swasta yang belum terbentuk } \\
\text { W3. Belum ada kerjasama dan } \\
\text { koordinasi lintas sektoral dan } \\
\text { regional } \\
\text { W4. Promosi dan sistem pemasaran } \\
\text { yang masih lemah } \\
\text { W5. Ketidakpastian hukum }\end{array}$ \\
\hline $\begin{array}{l}\text { Peluang (Opportunities) } \\
\text { O1. Investasi swasta skala } \\
\text { menengah \& besar } \\
\text { O2. Ketersediaan Kredit Usaha } \\
\text { Rakyat (KUR) } \\
\text { O3. Adanya PNPM Mandiri } \\
\text { Pariwisata }\end{array}$ & $\begin{array}{l}\text { (S }-\mathrm{O}) \\
\text { 1. Peningkatan peran pemerintah \& } \\
\text { swasta dalam mengembangkan } \\
\text { pariwisata }(\mathrm{S} 1, \mathrm{~S} 2, \mathrm{~S} 3, \mathrm{~S} 4, \mathrm{O} 1, \\
\mathrm{O} 2, \mathrm{O} 3) \\
\text { 2. Peningkatan kesejahteraan } \\
\text { masyarakat di sekitar objek } \\
\text { wisata di Kota Ambon }(\mathrm{S} 1, \mathrm{~S} 2 \text {, } \\
\mathrm{S} 3, \mathrm{O} 1, \mathrm{O} 2, \mathrm{O} 3)\end{array}$ & $\begin{array}{l}\text { (W-O) } \\
\text { 1. } \begin{array}{l}\text { Membangun kerjasama yang } \\
\text { saling menguntungkan antar } \\
\text { pemerintah, swasta dan } \\
\text { masyarakat }(\mathrm{W} 1, \mathrm{~W} 2, \mathrm{~W} 3, \mathrm{~W} 4, \\
\mathrm{W} 5, \mathrm{O} 1, \mathrm{O} 2, \mathrm{O} 3)\end{array} \\
\text { 2. Pengembangan sistem pemasaran } \\
\text { dan promosi kepariwisataan (W1, } \\
\text { W2, W3,W4, W5, O1, O2) } \\
\text { 3. Peningkatan dan Pengembangan } \\
\text { kerjasama kepariwisataan antar } \\
\text { stakeholder lokal, regional, dan } \\
\text { internasional } \\
\text { (W1,W2,W3,W4,W5,O1, O2,O3) }\end{array}$ \\
\hline $\begin{array}{l}\text { Ancaman (Threats) } \\
\text { T1. Travel warning dari Negara } \\
\text { lain } \\
\text { T2. Bencana alam } \\
\text { T3. Gangguan keamanan }\end{array}$ & $\begin{array}{l}(\mathrm{S}-\mathrm{T}) \\
\text { 1. } \\
\text { 1. Pemberlakuankebijakan } \\
\text { investasi yang kondusif } \\
(\mathrm{S} 1, \mathrm{~S} 2, \mathrm{~S} 3, \mathrm{~T} 1, \mathrm{~T} 2,)\end{array}$ & $(\mathrm{W}-\mathrm{T})$ \\
\hline
\end{tabular}


Selain itu juga berhasil dirumuskan enam strategi pembiayaan utama terhadap pengembangan pariwisata berbasis masyarakat di Kota Ambon, antara lain: 1) Membangun kerjasama yang saling menguntungkan antar pemerintah, swasta dan masyarakat (skor 6,880); 2) Peningkatan peran pemerintah dan swasta dalam mengembangkan pariwisata (skor 6,592); 3) Peningkatan kesejahteraan masyarakat di sekitar obyek wisata di Kota Ambon (skor 6,545); 4) Pemberlakuan kebijakan investasi yang kondusif (skor 6,285); 5) Peningkatan dan pengembangan kerjasama kepariwisataan antar stakeholder lokal dan regional (skor 6,509), serta 6) Pengembangan sistem pemasaran dan promosi kepariwisataan $(5,662)$.

\section{KESIMPULAN DAN SARAN}

\section{Kesimpulan}

1. Kebijakan pemerintah Kota Ambon dalam mengembangkan pariwisata berbasis masyarakat masih belum optimal. Masyarakat selaku basis pengembangan pariwisata khususnya di daerah obyek wisata di Kota Ambon juga belum berpartisipasi aktif, baik untuk pengembangan kepariwisataanya maupun terhadap peningkatan kesejahteraan mereka dari sektor tersebut.

2. Pembiayaan yang dilakukan baik oleh masyarakat, pemerintah maupun swasta masih belum dapat mengembangkan pariwisata berbasis masyarakat di Kota Ambon karena pemerintah dan swasta masih berjalan sendiri-sendiri.

3. Terdapat enam strategi pembiayaan terhadap pengembangan pariwisata berbasis masyarakat di Kota Ambon yang dapat dilaksanakan pada tahun 2011-2016. Selain itu, beberapa pola kerjasama pembiayaan yang dapat dilakukan meliputi pola kemitraan antara pemerintah dan swasta (public private partnership), Kredit Usaha
Rakyat (KUR), serta PNPM Mandiri Pariwisata.

\section{Saran}

Untuk efektifitas pelaksanaan pembiayaan pengembangan pariwisata berbasis masyarakat di Kota Ambon, maka disarankan beberapa hal kepada:

1. Pemerintah daerah, untuk meningkatkan integrasi program antara pemerintah Provinsi Maluku dan Kota Ambon, memberikan kemudahan fasilitas investasi bagi swasta, menjalin kerjasama dengan swasta melalui pola kemitraan, meningkatkan sosialisasi program Kredit Usaha Rakyat (KUR), dan meningkatkan alokasi anggaran sektor pariwisata di APBD Kota Ambon.

2. Pihak swasta, salah satunya untuk menjalin komunikasi dan koordinasi dengan pemerintah daerah terhadap pengembangan obyek wisata dalam kerangka pola kemitraan.

3. Masyarakat, untuk mengembangkan kerajinan khas Ambon dengan menjual secara kontinyu di lokasi obyek wisata, memanfaatakan program pemerintah Kredit Usaha Rakyat (KUR) dan PNPM Mandiri Pariwisata, serta memelihara dan bertanggung jawab terhadap kualitas fasilitas obyek wisata di wilayah sekitarnya. 


\section{DAFTAR PUSTAKA}

[ABS] Australian Bureau of Statistics. 1994. Framework for the Collection and publication of Tourism Statistics. Canberra: Australian Bureau of Statistics.

Baiquni M. 2004. Membangun Pusat-Pusat Pinggiran Otonomi di Negara Kepulauan. ASPEK, IDEAS. Yogyakarta.

Chib S.N. 1980. Financing Tourism Development: A Recipient's View. International Journal of Tourism Management: 231-237.

Choi H.S, Sirakaya E. 2005. Sustainability Indicators for Managing Community Tourism. Tourism Management 27 (2006) ; 12741289.

Cooper, C and J. Fletcher. 1993. Tourism, Principles And Practice. Essex: Longman Group Limited

Dinas Pariwisata Kebudayaa Pemuda dan Olahraga Kota Ambon, 2009. Anggaran Belanja dan Penerimaan Pariwisata Kota Ambon 20052008.

Dinas Pariwisata Kota Ambon. 2008. Objek Wisata dan Industri Pariwisata di Kota Ambon 2008.

Fennell D.A. (1999). Ecotourism : An Introduction. New York, NY : Routledge.

Goodwin, Harold. 2004. Tourism and Local Economic Development. The International Centre for Responsible Tourism dan Scott Wilson Business Consultancy.

Heriawan, Rusman. 2004. Peranan dan Dampak Pariwisata Pada Perekonomian Indonesia : Suatu Pendekatan Model I-O dan SAM [disertasi]. Program Pascasarjana. Bogor: Institut Pertanian Bogor.

Herremans, I.M \& Welsh C. (1999). Developing \& Implementing the Company's Ecotourism Mission Statement. Journal of Sustainable Tourism 7 (1); 48- 76.
Jay's. 2008. Peranan Pemerintah Daerah dalam pengembangan Kawasan Pariwisata Kota Batu Malang.

Leiper, N. 1979. The Framework of Tourism: Towards a Definition of Tourism, Tourist and Tourism Industry. Annals of Tourism Research. 6: 390-407.

Pitana, I Gede dan Gayatri Putu G. 2005. Sosiologi Pariwisata. Yogyakarta: Penerbit Andi.

Saleh, Harry H. 2008. Kemitraan Sektor Publik dan Swasta: Suatu Ikhtisar Pendekatan Pembangunan, Perluasan Bisnis dan Pelayanan Publik. Jakarta: Pustaka Sinar Harapan.

Santosa, SP. 2002. Pengembangan Pariwisata Indonesia. http://www.wisatamelayu.com/id/ar ticle.php?a=N2VIL3c\%3D [15 Okt 2009]

Sebele S.L. 2009. Community Based Tourism Ventures, Benefits and Challenges : Khama Rhino Sanctuary Trust, Central District, Botswana. Tourism Managemennt 31 (2010); 136-146.

Wahab, Salah. 1992. Pemasaran Pariwisata. Jakarta: PT. Prdnya Paramita.

Yoeti, Oka A. 2008.Ekonomi Pariwisata: Introduksi, Informasi dan Implementasi. Jakarta: Kompas. 